\title{
Effect of different phosphorus concentrations on growth and biochemical composition of Chaetoceros muelleri
}

\author{
José P. Lovio-Fragoso ${ }^{1}$, Corina Hayano-Kanashiro ${ }^{1}$ \& José A. López-Elías ${ }^{1}$ \\ ${ }^{1}$ Departamento de Investigaciones Científicas y Tecnológicas, Universidad de Sonora \\ Hermosillo, Sonora, México \\ Corresponding author: Corina Hayano-Kanashiro (angela.hayano@unison.mx)
}

\begin{abstract}
Chaetoceros muelleri is one of the most widely used microalgae species in aquaculture in northwestern Mexico as food for fish and crustaceans. Its importance is due to its fast growth, nutritional quality and lipid accumulation under nutrient-limiting conditions. However, the biochemical and molecular mechanisms of uptake of phosphorus $(\mathrm{P})$ limiting conditions for this species is still unknown. This study aimed to analyze the growth and biochemical composition of $C$ muelleri in response to different phosphorus concentrations. Four treatments under different phosphorus conditions were used: control (72 $\mu \mathrm{M} P)$, excess $(144 \mu \mathrm{M} \mathrm{P})$ and two treatments with phosphorus limitation, limited A (18 $\mu \mathrm{M} \mathrm{P})$ and limited B (7 $\mu \mathrm{M} \mathrm{P})$. The highest cell concentration was observed in control and excess of $\mathrm{P}\left(>3.4 \times 10^{6}\right.$ cells $\left.\mathrm{mL}^{-1}\right)$. The highest dry mass concentration and chlorophyll- $a$ content were found in control medium $(72 \mu \mathrm{M} \mathrm{P})$ whereas the highest total lipid $(4.42 \%)$ was found in the lowest P-concentration medium $(7 \mu \mathrm{M} P)$. No significant differences were found in the total protein content, but we did find differences between the treatments with phosphorus limitation (7 and $18 \mu \mathrm{M}$ P).
\end{abstract}

Keywords: Chaetoceros muelleri; biochemical composition; microalgae; phosphorus; proteins; lipids

Microalgae are unicellular photosynthetic organisms found in different habitats and a wide range of environmental conditions. Among the most important groups of microalgae in terms of abundance are diatoms, and recently they are gaining interest by its multiple applications and several studies have reported the modification of their biochemical composition by different parameters (Bozarth et al., 2009). In nature, diatoms frequently grow under nutrients limiting conditions and although nitrogen and iron have been reported as limiting nutrients; there is also evidence of phosphorus limitation (Girault et al., 2013). Phosphorus $(\mathrm{P})$ is an essential nutrient required for life and growth for all eukaryotic algae (Karl, 2014) that impacts in the primary production chain in oceans and estuarine environments (Paytan \& MacLaughlin, 2007). It is involved in different metabolic processes within cells (Karl, 2014) and in algae, the main reservoirs of phosphorus are nucleic acids and lipid membranes. Although the pool of P may be small, it is also a major component in nucleoside triphosphates like ATP and GTP, which are essential energy molecu- les in the cells (Dyhrman, 2016). Further, it is reported that the phosphorus concentrations are low in many marine environments (Dyhrman et al., 2012); and the high concentrations of $\mathrm{P}$ in wastewaters can cause eutrophication of rivers and lakes (Sforza et al., 2018). In that sense, it is suggested that the diatoms could fall phosphorus in the form of polyphosphate to the sea floor producing P-rich apatite sediments (Díaz et al., 2008). P deficiency can affect drastically cell metabolism; whereas the main cell membrane constituent is phospholipids; under $\mathrm{P}$ starvation is enhanced the formation and accumulation of neutral lipids such as triacylglycerides (Van Mooy et al., 2009; Dyhrman et al., 2016).

The genus Chaetoceros belonging to the class Bacillariophyceae is one of the largest genera of marine planktonic diatoms, and it is widely distributed around the world, with approximately 400 described species (Spaulding \& Edlund, 2008). In this genus, Chaetoceros muelleri is one of the most used microalgae in aquaculture in northwestern Mexico as food for crustaceans and fish, especially in shrimp farms, becau-

Corresponding editor: José Luis Iriarte 
se of its high lipid content (Leonardos \& Geider, 2004; López-Elías et al., 2005). Moreover, several studies have been carried out on $C$. muelleri focusing on its biochemical composition and the effects of several factors (Leonardos \& Geider, 2004; Wang et al., 2014). However, the studies on the influence of nutrients (either in excess or deficient levels) in C. muelleri are scarce. Therefore, this study aims to analyze the growth and chemical composition of $C$. muelleri at different phosphorus concentrations (excess and deficient media).

The strain of $C$. muelleri used in this study was isolated in Bahía de Kino (Sonora, Mexico) and maintained in the algal stock collection of the Departamento de Investigaciones Científicas y Tecnológicas, Universidad de Sonora, México. Axenic batch cultures of $C$. muelleri $(1 \mathrm{~L}$ Erlenmeyer glass flasks) were tested using F medium (Guillard \& Ryther, 1962), with modified phosphate concentrations. Four phosphorus treatments were used in this study, which includes control (phosphate: $72 \mu \mathrm{M}$ ), excess (phosphate: $144 \mu \mathrm{M})$ and two treatments with phosphorus limitation, which for practical purposes will be assigned as limited A (phosphate: $18 \mu \mathrm{M}$ ) and limited $\mathrm{B}$ (phosphate: $7 \mu \mathrm{M}$ ). Each treatment was performed by quadruplicate, and the concentrations of the other nutrients (nitrates, minerals, vitamins, and trace minerals) were kept constant, according to the $\mathrm{F}$ medium. The diatom was inoculated with 150,000 cells $\mathrm{mL}^{-1}$ in all treatments and maintained under the following conditions: temperature was maintained at 22 $\pm 1^{\circ} \mathrm{C}$ with continuous light irradiance $220 \mu \mathrm{mol} \mathrm{m}^{-2} \mathrm{~s}^{-1}$ (Phillips F96T8/TL865, $60 \mathrm{~W}$ ), salinity 30, without aeration.

Cell density was determined by taking a daily sample of one aliquot from each treatment and fixed with Lugol's solution (1\%). Quantification of the cell density was performed for nine days, using the direct counting technique with a hematocytometer of $0.1 \mathrm{~mm}$ depth in a microscope. The data of the cellular concentrations were transformed to $\log _{2}$ to obtain the growth rates (number of divisions per day). The formula used to calculate growth rate $(\mu)$ (BecerraDórame et al., 2010) was: $\mu=\log _{2} C_{n}-\log _{2} C_{n-1} /\left(t_{n}-t_{n-1}\right)$, where $\mu$ was considered as the growth rate, $C_{n}$ as microalgae density (cells $\mathrm{mL}^{-1}$ ) at day $n$.

For biochemical analysis, samples were collected on day 4, which was the time that all treatments reached the late log phase. For biomass determination (dry weight), the cultures were homogenized, and culture samples were filtered through a previously dried and weighted $47 \mathrm{~mm}$ glass microfiber filter (GFF; Whatman). Afterwards, filtered cells were washed with ammonium formate $\left(36 \mathrm{~g} \mathrm{~L}^{-1}\right)$ to remove salt precipitates and dried at $60^{\circ} \mathrm{C}$ for $8 \mathrm{~h}$ to achieve a constant weight in a convection stove. Further, samples were burned in a muffle-furnace at $480^{\circ} \mathrm{C}$ for $12 \mathrm{~h}$ and weighted in an analytical balance (Ohaus Explorer Analytical Balance Ohaus E011403) to obtain the inorganic content (ashes). The difference between biomass and ashes determined the organic matter.

For Chl- $a$ determination, $50 \mathrm{~mL}$ of homogenized algal cells were harvested and centrifuged at 2,000 $\mathrm{g}$ for 5 min. Photosynthetic pigments were extracted from the cell pellet using 90\% acetone, followed by sonication (Sonic 1510 R-DTH Branson Ultrasonics Corporation, CT, USA) for $5 \mathrm{~min}$. Subsequently, the extracts were stored in darkness for $24 \mathrm{~h}$ at $4^{\circ} \mathrm{C}$. The Chl- $a$ content was determined spectrophotometrically and following the equation of Jeffrey \& Humphrey (1975).

For total lipid and protein content determination, culture samples were filtered through $25 \mathrm{~mm}$ diameter GFF filters (Whatman) and filtered cells were washed with ammonium formate $\left(36 \mathrm{~g} \mathrm{~L}^{-1}\right)$. The filters were stored at $-20^{\circ} \mathrm{C}$ before further chemical analysis. Total lipid content was determined colorimetrically according to Pande et al. (1963). After being extracted, the method of Bligh \& Dyer (1959) modified by LópezElías et al. (1993) was used. Total protein content was determined colorimetrically according to the method of Lowry et al. (1951) modified by Malara \& Charra (1972) and following the recommendation for its extraction by Clayton et al. (1988) and López-Elías (1993). Quantification of total lipid and protein content were performed with a spectrophotometer (Cary 100 BIO UV-Visible Spectrophotometer).

Cell concentration, biomass, and biochemical composition data were analyzed with descriptive statistics (average and standard deviation) and to determine differences among treatments, an analysis of one-way ANOVA and a Tukey test was performed with significance level of $\alpha=0.05$ using the statistical package Statgraphics Centurion XV (Statpoint Inc., USA) for Windows. The data presented were performed using four biological replicates, and each biological replicate came from three technical replicates for each treatment of $\mathrm{P}$ concentration in all determinations for each parameter (dry biomass, organic matter, $\mathrm{Chl}-a$, lipids, and proteins).

In cultures with lower $\mathrm{P}$ concentrations, growth and cell densities were significantly lower, observing cell densities of $21.81 \pm 0.22 \log _{2}\left(3.52 \times 10^{6}\right.$ cells $\mathrm{mL}^{-1}, 18$ $\mu \mathrm{M})$ and $21.27 \pm 0.27 \log _{2}\left(2.56 \times 10^{6}\right.$ cells $\left.\mathrm{mL}^{-1}, 7 \mu \mathrm{M}\right)$ $(P<0.05)$. The treatments with the highest cell densities of $C$. mueller $i$ were those with 72 and $144 \mu \mathrm{M}$ of $P$ concentration of $22.23 \pm 0.11 \log _{2}\left(4.94 \times 10^{6}\right.$ cells $\left.\mathrm{mL}^{-1}\right)$ and $22.26 \pm 0.08 \log _{2}\left(5.04 \times 10^{6}\right.$ cells mL $\left.\mathrm{mL}^{-1}\right)$ res- 


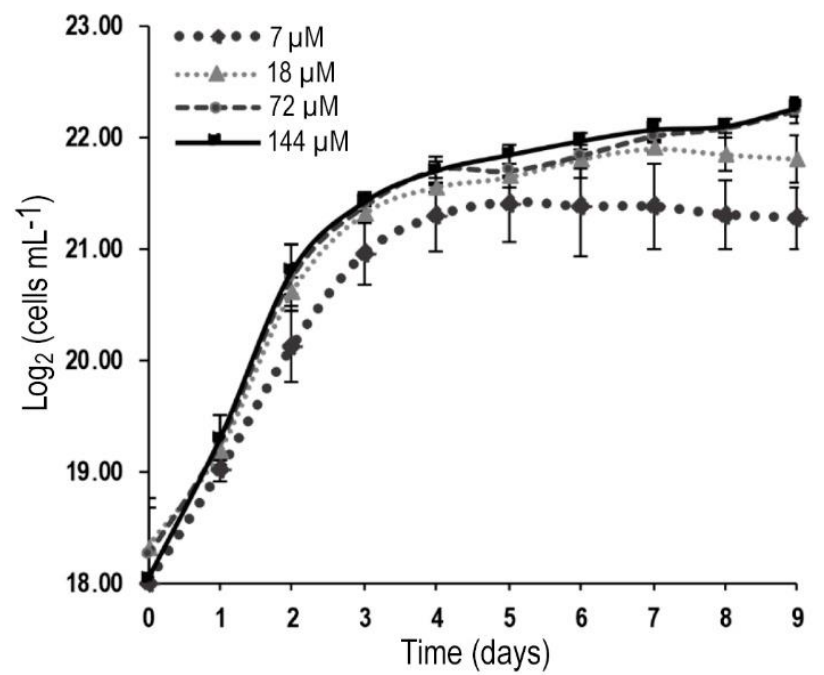

Figure 1. Growth curves of Chaetoceros muelleri at different $\mathrm{P}$ concentrations.

pectively with no significant differences between treatments $(P<0.05)$ (Fig. 1). The maximum growth rate was achieved at $144 \mu \mathrm{M} P(1.51 \pm 0.21)$ and the lowest rate at $7 \mu \mathrm{M} P(1.11 \pm 0.32)$; the accumulated and mean growth rates increased as the $\mathrm{P}$ concentration increased, although no significant differences were found among treatments (Table 1).

The highest production of dry biomass was found in the culture medium with $72 \mu \mathrm{M}$ P concentration (311.42 $\left.\pm 12.3 \mathrm{mg} \mathrm{L}^{-1}\right)$; no significant differences were found in treatments with $\mathrm{P}$ concentrations of $18 \mu \mathrm{M}$ $\left(250.26 \pm 11.2 \mathrm{mg} \mathrm{L}^{-1}\right)$ and $144 \mu \mathrm{M}(248.07 \pm 11.7 \mathrm{mg}$ $\left.\mathrm{L}^{-1}\right)$. The lowest production of dry biomass was registered at phosphorus concentration of $7 \mu \mathrm{M}$ (199.92 $\pm 2.7 \mathrm{mg} \mathrm{L}^{-1}$ ). The highest Chl- $a$ content was observed in culture medium with $\mathrm{P}$ concentration of $72 \mu \mathrm{M}$ $\left(0.5064 \pm 0.11 \mu \mathrm{g} \mathrm{mL}^{-1}\right)$ followed by the treatments of 144,18 and $7 \mu \mathrm{M}$; significant differences were found among all the treatments $(P<0.05)$ (Table 2$)$.

We did find differences between 7 and $18 \mu \mathrm{M} P$ concentration treatments; however, the rest of the treatments did not show significant differences $(P<$ 0.05 ) (Table 2). The highest lipid content was observed in the culture medium with the lowest concentration of $\mathrm{P}(7 \mu \mathrm{M})$, followed by a $\mathrm{P}$ concentration of $18 \mu \mathrm{M}$ with significant differences between treatments $(P<0.05)$. Cultures with a higher concentration of P (72 and 144 $\mu \mathrm{M})$ had lower lipid content than the limited $\mathrm{P}$ cultures with no significant differences between them (Table 2).

In the present study, we found the highest cellular concentration in medium with an excess of $\mathrm{P}(144 \mu \mathrm{M})$ at the end of the culture. Mean rate and accumulated rate were lower in $\mathrm{P}$ limitation $(7 \mu \mathrm{M})$, due to the slow culture growth. Phosphorus is an essential component for the conversion of solar energy into biochemical energy and necessary for the normal growth, development, and synthesis of biochemical compounds such as nucleic acids and lipid membranes in eukaryotic algae, and there is evidence that phosphorus is the main limiting nutrient in many natural environments instead of nitrogen (Dyhrman, 2016). Immediate effects to phosphorus limitation include a reduction in the synthesis and regeneration of substrates in the Calvin-Benson cycle and consequently, a reduction in the use of light energy for carbon fixation, resulting in low biomass production and low growth rates (Belotti et al., 2013; Dyhrman, 2016). In this study, we observed low biomass production at the lowest $\mathrm{P}$ concentration $(7 \mu \mathrm{M})$.

Regarding the biochemical composition, samples were taken at the late logarithmic phase, because it has been reported that in this phase, the maximum production of lipids is generated (Belotti et al., 2013). Further, it has been suggested that in microalgae species with moderate amounts of lipids could be possible to improve these amounts by modifying the culture conditions and nutrient availability. In that sense, it is well documented that under deficient nutrient conditions, neutral lipids synthesis is favored and can be used as an alternative source of biofuels; therefore, it is necessary to find the most suitable species and define the culture conditions that could help to achieve this purpose (Vuppaladadiyam et al., 2018; Zulu et al., 2018).

The highest Chl- $a$ content was found in culture with the optimal concentration of $\mathrm{P}(72 \mu \mathrm{M})$; treatments with $\mathrm{P}$ deficiency showed a lower amount of Chl- $a$. The low content of Chl- $a$ cannot be attributed directly to $\mathrm{P}$ deficiency since its molecule does not contain it. However, Roopnarain et al. (2014) suggested that this decrease occurs because of the inability of the cells to produce ATP and NADPH, which are important molecules involved in its synthesis, affecting all the metabolism and as a strategy of the cell in giving priority to the synthesis of storage compounds. On the other hand, it has been reported that also at higher nutrient concentrations, Chl- $a$ content tends to decrease (Fabregas et al., 1985). In the present study, we also observed this behavior in the treatment of $144 \mu \mathrm{M} P$ concentration.

The highest total lipid content was observed in culture with the lowest concentration of P $(7 \mu \mathrm{M})$, and it was observed that the total lipid content decreased as the $\mathrm{P}$ concentration increased. It has been widely documented in several species of microalgae that under phosphate deficiency, accumulation of neutral lipids is a common response and it has been observed that phospholipid levels in cells are reduced and being repla- 
Table 1. Cell densities and growth rates of development of the cultures, under different concentrations of $\mathrm{P}$ and one-way ANOVA analyses results. Values are means \pm standard error. Values in the same column with different superscript present significant statistical differences at $P<0.05$.

\begin{tabular}{ccccc}
\hline $\begin{array}{c}\text { Phosphorus } \\
\text { concentration }\end{array}$ & $\begin{array}{c}\text { Cell density at the } \\
\text { end of the culture } \\
(9 \text { days })\left(10^{6} \mathrm{~mL}^{-1}\right)\end{array}$ & $\begin{array}{c}\text { Maximum rate }(\mu) \\
\text { division d } \mathrm{d}^{-1}\end{array}$ & $\begin{array}{c}\text { Accumulated } \\
\text { rate }(\mu)\end{array}$ & $\begin{array}{c}\text { Mean rate }(\mu) \\
\text { division } \mathrm{d}^{-1}\end{array}$ \\
\hline $7 \mu \mathrm{M}$ & $2.60 \pm 0.50^{\mathrm{a}}$ & $1.11 \pm 0.32^{\mathrm{a}}$ & $3.26 \pm 0.50^{\mathrm{a}}$ & $0.36 \pm 0.05^{\mathrm{a}}$ \\
$18 \mu \mathrm{M}$ & $2.94 \pm 0.29^{\mathrm{ab}}$ & $1.43 \pm 0.01^{\mathrm{b}}$ & $3.49 \pm 0.26^{\mathrm{a}}$ & $0.39 \pm 0.03^{\mathrm{a}}$ \\
$72 \mu \mathrm{M}$ & $3.40 \pm 0.18^{\mathrm{b}}$ & $1.48 \pm 0.15^{\mathrm{b}}$ & $4.00 \pm 0.34^{\mathrm{a}}$ & $0.44 \pm 0.04^{\mathrm{a}}$ \\
$144 \mu \mathrm{M}$ & $3.42 \pm 0.30^{\mathrm{b}}$ & $1.51 \pm 0.21^{\mathrm{b}}$ & $4.24 \pm 0.80^{\mathrm{a}}$ & $0.47 \pm 0.09^{\mathrm{a}}$ \\
\hline
\end{tabular}

Table 2. Chaetoceros muelleri, growing under different $\mathrm{P}$ concentrations: biomass $\left(\mathrm{mg} \mathrm{L}^{-1}\right)$, final biochemical composition and one-way ANOVA analyses results. Values are means \pm standard error. Values in the same column and with different superscript present significant statistical differences at $P<0.05$.

\begin{tabular}{cccccc}
\hline $\begin{array}{c}\text { Phosphorus } \\
\text { concentration }\end{array}$ & $\begin{array}{c}\text { Dry biomass } \\
\left(\mathrm{mg} \mathrm{L}^{-1}\right)\end{array}$ & $\begin{array}{c}\text { Chlorophyll- } a \\
\left.(\mu \mathrm{g} \mathrm{mL})^{-1}\right)\end{array}$ & $\begin{array}{c}\text { Organic } \\
\text { matter }(\%)\end{array}$ & $\begin{array}{c}\text { Lipid } \\
(\%)\end{array}$ & $\begin{array}{c}\text { Protein } \\
(\%)\end{array}$ \\
\hline $7 \mu \mathrm{M}$ & $199.92 \pm 2.7^{\mathrm{a}}$ & $0.1078 \pm 0.03^{\mathrm{a}}$ & $44.60 \pm 1.66^{\mathrm{a}}$ & $4.42 \pm 0.44^{\mathrm{a}}$ & $4.29 \pm 0.50^{\mathrm{a}}$ \\
$18 \mu \mathrm{M}$ & $250.26 \pm 11.2^{\mathrm{b}}$ & $0.1759 \pm 0.69^{\mathrm{b}}$ & $51.11 \pm 1.41^{\mathrm{b}}$ & $3.73 \pm 0.64^{\mathrm{b}}$ & $3.80 \pm 0.52^{\mathrm{b}}$ \\
$72 \mu \mathrm{M}$ & $311.42 \pm 12.3^{\mathrm{c}}$ & $0.5064 \pm 0.11^{\mathrm{c}}$ & $49.43 \pm 0.81^{\mathrm{b}}$ & $3.27 \pm 0.56^{\mathrm{c}}$ & $3.81 \pm 0.57^{\mathrm{b}}$ \\
$144 \mu \mathrm{M}$ & $248.07 \pm 11.7^{\mathrm{b}}$ & $0.4375 \pm 0.17^{\mathrm{d}}$ & $56.18 \pm 1.78^{\mathrm{c}}$ & $3.18 \pm 0.46^{\mathrm{c}}$ & $4.22 \pm 0.63^{\mathrm{b}}$ \\
\hline
\end{tabular}

ced by non-phosphorus lipids (Van Mooy et al., 2009; Cruz de Carvalho et al., 2016). Recently, Lin et al. (2018) evaluated N, Si and P deprivation in C. muelleri, reporting under $\mathrm{P}$ deprivation a total lipid content of $26.74 \pm 1.00 \%$ DW which was higher compared to the control treatment (f/2 media without nutrient deprivation), in which it was reported a total lipid content of $22.23 \pm 1.44 \% \mathrm{DW}$; this response is similar to what was observed in the present study. Although the values reported by Lin et al. (2018) are higher than those reported in this study, it is worth to mention that the laboratory's conditions vary among them, as well as the experimental design, the culture media, and the strains; these factors could influence in the final results.

On the other hand, although the protein content was higher in culture with the lowest concentration of $\mathrm{P}$ (7 $\mu \mathrm{M})$, no significant differences were found among treatments, but we did find differences between the treatments of $\mathrm{P}$ starvation $(7$ and $18 \mu \mathrm{M})$. Berdalet et al. (1994) studied the effects of nitrogen and phosphorus starvation on nucleic acids and protein content in Heterocapsa sp. They reported that under P starvation the synthesis of proteins would continue if nitrogen remains available at least in an initial period (Berdalet et al., 1994). Liang et al. (2013) found that Chlorella sp. showed no apparent change in protein content under P limitation. They concluded that the limitation by nitrogen would cause a decrease in the protein content instead of $\mathrm{P}$, and the differential response to nutrients limitation will vary depending on algae species and this statement agrees with several studies (Berdalet et al., 1994; Zhao et al., 2009).

On the other hand, Velasco et al. (2016) reported 59 $\pm 0.9 \%$ protein content and $31 \pm 1.3 \%$ lipid content (based in organic matter) for a strain of C. muelleri native from the Caribbean Sea; they evaluated its growth in the $\mathrm{f} / 2$ media with temperature of $24 \pm 0.5^{\circ} \mathrm{C}$, water salinity at 35 , and compressed air injected and constant illumination of $45 \mu \mathrm{mol} \mathrm{m} \mathrm{m}^{-2} \mathrm{~s}^{-1}$. These conditions differ from those established in the present study and may influence the different results. In this study was found a high protein content in the treatment with $144 \mu \mathrm{M}$ P concentration compared to treatments with 18 and $72 \mu \mathrm{M} \mathrm{P}$ concentration, which would suggest that with a greater amount of $\mathrm{P}$ present, ATP synthesis would increase and therefore could have a high production of proteins. However, additional work is required, such as transcriptomics and proteomics studies to gain a broader understanding of the P effect on Chaetoceros muelleri growth and its biochemical composition.

\section{ACKNOWLEDGMENTS}

The present research was financially supported by the Mexican Research Council-Consejo Nacional de Ciencia y Tecnología (CONACyT)-project $\mathrm{N}^{\circ} 000000000257155$. The authors would like to thank Luis Ángel MedinaJuárez, Claudia Celeste Molina-Domínguez and Álvaro Murguía-López for their technical assistance. J.P. Lovio- 
Fragoso also thanks to the Ph.D. fellowship from CONACYT (549662).

\section{REFERENCES}

Belotti, G., Bravi, M., de Caprariis, B., de Filippis, P. \& Scarsella, M. 2013. Effect of nitrogen and phosphorus starvations on Chlorella vulgaris lipids productivity and quality under different trophic regimens for biodiesel production. American Journal of Plant Sciences, 4(12): 44-51. doi.org/ 10.4236/ajps.2013. 412A2006.

Becerra-Dórame, M., López-Elías, J.A. \& MartínezCórdova, L.R. 2010. An alternative outdoor production system for the microalgae Chaetoceros muelleri and Dunaliella sp. during winter and spring in Northwest Mexico. Aquacultural Engineering, 43(1): 24-28. doi.org/10.1016/ j.aquaeng.2010.03.002

Berdalet, E., Latasa, M. \& Estrada, M. 1994. Effects of nitrogen and phosphorus starvation on nucleic acid and protein content of Heterocapsa sp. Journal of Plankton Research, 16(4): 303-316. doi.org/ 10.1093/plankt/ 16.4.303.

Bligh, E.G. \& Dyer, W.J. 1959. A rapid method of total lipid extraction and purification. Canadian Journal of Biochemistry and Physiology, 37(8): 911-917. doi. org/10.1139/059-099.

Bozarth, A., Maier, U.G. \& Zauner, S. 2009. Diatoms in biotechnology: modern tools and applications. Applied Microbiology and Biotechnology, 82(2): 195201. doi.org/10.1007/ s00253-008-1804-8.

Clayton, J.R., Dortch, Q., Thoresen, S.S. \& Ahmed, S.I. 1988. Evaluation of methods for the separation and analysis of proteins and free amino acids in phytoplankton samples. Journal of Plankton Research, 10(3): 341-358. doi.org/10.1093/plankt/10.3.341.

Cruz de Carvalho, M.H., Sun, H.X., Bowler, C. \& Chua, N.H. 2016. Noncoding and coding transcriptome responses of a marine diatom to phosphate fluctuations. New Phytologist, 210(2): 497-510. doi.org/ 10.1111/nph.13787.

Diaz, J., Ingall, E., Benitez-Nelson, C., Paterson, D., de Jonge, M.D., McNulty, I. \& Brandes, J.A. 2008. Marine polyphosphate: a key player in geologic phosphorus sequestration. Science, 320(5876): 652655. doi.org/10.1126/science. 1151751.

Dyhrman, S.T. 2016. Nutrients and their acquisition: phosphorus physiology in microalgae. In: Borowitzka, M., Beardall, J. \& Raven, J. (Eds.). The physiology of microalgae. Developments in Applied Phycology. Springer International Publishing, Berlin, 6: 155-183. doi.org/10.1007/978-3-319-24945-2_8.

Dyhrman, S.T., Jenkins, B.D., Rynearson, T.A., Saito, M.A., Mercier, M.L., Alexander, H., Whitney, L.P.,
Drzewianowski, A., Bulygin, V.V., Bertrand, E.M., Wu, Z.J., Benitez-Nelson, C. \& Heithoff, A. 2012. The transcriptome and proteome of the diatom Thalassiosira pseudonana reveal a diverse phosphorus stress response. Plos One, 7: e33768. doi.org/10.1371 /journal.pone.0033768.

Fabregas, J., Herrero, C., Abalde, J. \& Cabezas, B. 1985. Growth, chlorophyll a and protein of the marine microalga Isochrysis galbana in batch cultures with different salinities and high nutrient concentrations. Aquaculture, 50(1-2): 1-11. doi.org/10.1016/00448486(85)90147-4.

Girault, M., Arakawa, H. \& Hashihama, F. 2013. Phosphorus stress of microphytoplankton community in the western subtropical North Pacific. Journal of Plankton Research, 35: 146-157. doi.org/10.1093/ plankt/fbs076.

Guillard, R.R. \& Ryther, J.H. 1962. Studies of marine planktonic diatoms: I. Cyclotella nana Hustedt, and Detonula confervacea (Cleve) Gran. Canadian Journal of Microbiology, 8(2): 229-239. https://doi.org/ 10.1139/m62-029.

Jeffrey, S.T. \& Humphrey, G. 1975. New spectrophotometric equations for determining chlorophylls $a, b$, $\mathrm{c} 1$, and $\mathrm{c} 2$ in higher plants, algae, and natural phytoplankton. Biochemie und Physiologie der Pflanzen, 167 (19): 191-194. doi.org /10.1016/S00153796(17)30778-3.

Karl, D.M. 2014. Microbially mediated transformations of phosphorus in the sea: new views of an old cycle. Annual Review of Marine Science, 6(1): 279-337. doi.org/10.1146/annurev-marine-010213-135046.

Leonardos, N. \& Geider, R.J. 2004. Responses of elemental and biochemical composition of Chaetoceros muelleri to growth under varying light and nitrate: phosphate supply ratios and their influence on critical N:P. Limnology and Oceanography, 49(6): 2105-2114. doi.org/10.4319/ lo.2004.49.6.2105.

Liang, K., Zhang, Q., Gu, M. \& Cong, W. 2013. Effect of phosphorus on lipid accumulation in freshwater microalga Chlorella sp. Journal of Applied Phycology, 25: 311-318. doi.org/ 10.1007/s10811-012-9865-6.

Lin, Q., Zhuo, W.H., Wang, X.W., Chen, C.P., Gao, Y.H. \& Liang, J.R. 2018. Effects of fundamental nutrient stresses on the lipid accumulation profiles in two diatom species Thalassiosira weissflogii and Chaetoceros muelleri. Bioprocess and Biosystems Engineering, 41: 1213-1224. doi.org/10.1007/s00 449-018-1950-z.

López-Elías, J.A., Voltolina, D., Enríquez-Ocaña, F. \& Gallegos-Simental, G. 2005. Indoor and outdoor mass production of the diatom Chaetoceros muelleri in a Mexican commercial hatchery. Aquacultural Engineering, 33: 181-191. doi.org/10.1016/j.aquaeng. 2005.01.001. 
López-Elías, J.A \& Voltolina, D. 1993. Semicontinuous cultures of four microalgae with a nonconventional medium. Ciencias Marinas, 19(2): 169-180. doi.org/ 10.7773/cm.v19i2.930.

Lowry, O.H., Rosebrough, N.J., Farr, A.L. \& Randall, R.J. 1951. Protein measurement with the Folin phenol reagent. Journal of Biological Chemistry, 193(1): 265275.

Malara, G. \& Charra, R. 1972. Dosage des glucides particulaires de phytoplancton selon la méthode de Dubois. Université de Paris, Station Zoologique de Villefranche-sur-Mer, Notes de Travail, 6: 1-12.

Pande, S.V., Khan, R.P. \& Venkitasubramanian, T.A. 1963. Microdetermination of lipids and serum total fatty acids. Analytical Biochemistry, 6(5): 415-423. doi.org/10.1016/0003-2697(63)90094-0.

Paytan, A. \& McLaughlin, K. 2007. The oceanic phosphorus cycle. Chemical Reviews, 107(2): 563576. doi.org/10.1021/cr0503613.

Roopnarain, A., Gray, V.M. \& Symb, S.D. 2014. Phosphorus limitation and starvation effects on cell growth and lipid accumulation in Isochrysis galbana U4 for biodiesel production. Bioresource Technology, 156: 408-411. doi.org/10.1016/j.biortech.2014.01. 092.

Sforza, E., Calvaruso, C., La Rocca, N. \& Bertucco, A. 2018. Luxury uptake of phosphorus in Nannochloropsis salina: effect of $\mathrm{P}$ concentration and light on $\mathrm{P}$ uptake in batch and continuous cultures. Biochemical Engineering Journal, 134: 69-79. doi.org/10.1016/j.bej.2018.03.008.

Spaulding, S. \& Edlund, M. 2008. Chaetoceros. Diatoms of the United States. [http://westerndiatoms. Colorado.edu/taxa/genus/chaetoceros]. Reviewed: 1 May 2017.

Received: 24 February 2018; Accepted: 23 October 2018
Van Mooy, B.A.S., Fredricks, H.F., Pedler, B.E., Dyhrman, S.T., Karl, D.M., Koblížek, M., Lomas M.W., Mincer, T.J., Moore, L.R., Moutin, T., Rappé, M.S. \& Webb, E.A. 2009. Phytoplankton in the ocean uses non-phosphorus lipids in response to phosphorus scarcity. Nature, 458: 69-72. doi.org/10.1038/nature 07659.

Velasco, L.A., Carrera, S. \& Barros, J. 2016. Isolation, culture, and evaluation of Chaetoceros muelleri from the Caribbean as food for the native scallops, Argopecten nucleus and Nodipecten nodosus. Latin American Journal of Aquatic Research, 44(3): 557568. doi.org/10.3856/vol44-issue3-fulltext-14.

Wang, X.W, Liang, J.R., Luo, C.S., Chen, C.P. \& Gao, Y.H. 2014. Biomass, total lipid production, and fatty acid composition of the marine diatom Chaetoceros muelleri in response to different $\mathrm{CO}_{2}$ levels. Bioresource Technology, 161: 124-130. doi.org/10.10 16/j.biortech.2014.03.012.

Zhao, Y.F., Yu, Z, Song, X.X. \& Cao, X.H. 2009. Biochemical compositions of two dominant bloomforming species isolated from the Yangtze River Estuary in response to different nutrient conditions. Journal of Experimental Marine Biology and Ecology, 368: 30-36. doi. org/10.1016/j.jembe.2008.09.023.

Vuppaladadiyam, A.K., Prinsen, P., Raheem, A., Luque, R. \& Zhao, M. 2018. Microalgae cultivation and metabolites production: a comprehensive review. Biofuels, Bioproducts and Biorefining, 12(2): 304-324. doi.org/10.1002/bbb.1864.

Zulu, N.N., Zienkiewicz, K., Vollheyde, K. \& Feussner, I. 2018. Current trends to comprehend lipid metabolism in diatoms. Progress in Lipid Research, 70: 1-16. doi.org/10.1016/j.plipres.2018.03.001. 